\title{
Policy Implementation Strategy of West Bandung District Health Office in Stunting Intervention During COVID-19 Pandemic
}

\author{
Strategi Implementasi Kebijakan Dinas Kesehatan Kabupaten Bandung Barat \\ dalam Intervensi Stunting pada Masa Pandemi COVID-19
}

\section{Fitri Aditri, S.Gz ${ }^{*}$, Dian Luthfiana Sufyan, S.Gz, M.Gizi1, Luh Desi Puspareni, ST.Gizi, M.Gizi ${ }^{1}$}

${ }^{1}$ Nutrition Study Program, Faculty of Health Sciences, Universitas Pembangunan Nasional Veteran Jakarta, Indonesia

\section{* Email corresponding author: fitriaditri@upnvj.ac.id}

\begin{abstract}
The government has a target of reducing stunting to 14\% by 2024. However, the COVID-19 pandemic has the potential to disrupt the government's focus in reducing stunting, including the West Bandung District Health Office, whose area is the focus location for stunting since 2018. This research aims to explore policy implementation strategies West Bandung District Health Officein stunting intervention during the COVID-19 pandemic. The method used in this research is descriptive qualitative with a case study approach. The research informants were 4 people who were officials in the work area of the West Bandung District Health Office and including the inclusion criteria. Data were collected by in-depth interviews, documentation, and triangulation. After processing and analyzing the data, the following results were obtained: The strategy for implementing the policies of the West Bandung District Health Office in stunting interventions, especially specific nutrition interventions during the COVID-19 pandemic, including through a role-sharing approach, take advantage of digital media, every activity carried out in accordance with COVID-19 health protocols, Holding Integrated Healthcare Center "Sweeping", using priority strategies to streamline the budget, and synergize the COVID-19 prevention program with stunting.. Despite having a special strategy, the increasein the prevalence of stunting during the COVID-19 pandemic in West Bandung District is unavoidable
\end{abstract}

Keyword: COVID-19 Pandemic, Stunting, Policy Implementation Strategy, West Bandung District Health Office

\section{INTRODUCTION}

Stunting is a major health problem for children under five in Indonesia. Trends in the prevalence of stunting under five in Indonesia tend to be static. The the Indonesian basic health surveys of 2007, 2013, and 2018 show the prevalence of stunted toddlers in Indonesia is an average of $35.1 \%$ (1-3). The latest national survey, namely the Indonesian Toddler Nutrition Status Survey (SSGBI) in 2019 stated that the prevalence of stunting under five in Indonesia was $27.67 \%$ (4). Although the prevalence of stunting under five shows a decline, until now the prevalence of stunting in Indonesia is still above $20 \%$ (the threshold set by WHO) and when compared with other nutritional problems such as underweight, wasting, and overweight in children under five, stunting is a problem with the highest prevalence $(5,6)$. Stunting toddlers (dwarf) have a lower length or height when compared to their age. However, stunting is not just short, but has serious consequences in the short and long term that are detrimental to the health side of a nation's economy (7). Therefore, the Indonesian government is targeting a 14\% reduction in stunting by 2024 (8). 
However, the government's focus on achieving the stunting reduction target has the potential to be disrupted because starting in March 2020 Indonesia was hit by the COVID-19 pandemic. Various parties and the mass media have stated that the COVID19 pandemic has the potential to increase the prevalence of stunting. Several indicators that show the potential for an increase in stunting during the COVID-19 pandemic include a decrease in Posyandu (Integrated Healthcare Center) and Puskesmas (Public Health Center) activities, a decrease in income and access to nutritious food for the community, and the large-scale social restrictions policy (9). In addition, funds for handling stunting have also decreased due to budget refocusing for COVID-19 (10). The United Nation International Children Emergency Fund (UNICEF) even predicts that the number of under-five children who are malnourished globally will increase by around $15 \%$ by 2020 (11).

West Bandung District is one of the priority Regencys for stunting handling because in 2013, West Bandung District was the Regency with the highest prevalence of stunting in West Java, which was $52.55 \%$ (12). Until 2019, the prevalence of stunting in West Bandung District was still above the national prevalence, which was $32.12 \%$ (13). In addition, stunting in West Bandung District has a unique cause, which is not directly related to economic conditions and access to nutritious food $(14,15)$. Meanwhile, the factors that influence the incidence of stunting in West Bandung District include the lack of knowledge of maternal nutrition regarding the intake needs for child growth and development since pregnancy (16), inadequate parenting that causes inadequate prenatal nutrition, breastfeeding and complementary feeding is not adequate, a history of illness suffered by toddlers in the form of fever and diarrhea, and a history of incomplete immunizations (17). In addition, not all pregnant women want to go to Posyandu (18) so that a nutrition intervention strategy is needed, especially specific nutrition interventions.

The Health Department is a regency/city regional apparatus organization that has a strategic role. In the guidelines for the implementation of integrated stunting interventions in Regencys/cities form State Minister for Chairperson of the National Development Planning Agency, the Health Office specifically has a mapping of tasks in specific nutrition interventions. Therefore, researchers are interested in understanding the social situation in depth and digging for more comprehensive information related to the policy implementation strategy of the West Bandung District Health Office in stunting interventions during the COVID-19 pandemic.

\section{METHODS}

This research is a descriptive qualitative research with a case study approach. The time of the study was carried out in January - February 2021 in the work area of the West Bandung District Health Office. The population in this study is the government apparatus in the work area of the West Bandung District Health Office. Sampling was done by purposive sampling and snowball sampling. The inclusion criteria in this study were that the informant was an official involved in the governance of the stunting program, had worked for at least 2 years, and was not involved in a conflict of interest. The exclusion criteria were people who did not provide information, were sick or did not enter at the time of data collection. With this sampling technique and criteria, four informants were obtained, namely the Head of the Public Health Division and the Staff of the Nutrition Section of the West Bandung District Health Office as the main informants, and the Head and Nutrition Officer of the Sindangkerta Health Center 
as additional informants. Data was collected by means of in-depth interviews, documentation studies, and triangulation. The research instrument in qualitative research is the researcher himself who is assisted by semi-structured questionnaires, matrix checklists, notebooks, voice recorders, and cameras. Data analysis using Microsoft Word and Microsoft Excel with the stages of transcribing data (nonverbatim), listening and reading repeatedly, labeling/coded to form themes and subthemes, validating and selecting data to reach conclusions.

\section{RESULTS AND DISCUSSION}

\section{A. Overview of Research Location}

This research was conducted at the West Bandung District Health Office and Sindangkerta Health Center. West Bandung District is one of the priority Regencys for stunting management. The programs that have been run by the West Bandung District Health Office and its network include the program for providing supplementary feeding for stunting toddlers, training cadres to become PMBA (feeding babies and children) counselors, successing Open Defecation Free (ODF), classes for pregnant women, classes for mothers of toddlers, breastfeeding support groups, PMBA support groups, especially in locus areas, routine weighing, giving vitamin A, counseling on first 1000 days of life, sanitation activities, immunization, giving zinc, promoting prevention of stunting and cross-sectoral activities such as PEHABA program (a program for pregnant women and toddlers). Besides focusing on specific interventions, the West Bandung District Health Office also does not rule out the possibility to be involved in sensitive intervention activities carried out by other sectors such as advocating or providing input to cross-sectoral related stunting prevention and control programs. In addition, each Puskesmas as a network of the Health Department also has its own innovation program, such as the Sindangkerta Health Center which has an innovation program named Ikan Bakar and Goreng Mas Kepiting which works the same as the Religious Affairs Office, the Education Office, and Agriculture Office.

\section{B. Characteristics of Research Informants}

All informants in this study were female. The main informant works at the West Bandung District Health Office who serves as Head of Public Health and Nutrition Section Staff. The Head of Public Health is a Master of Public Health graduate who has worked for 32 years at the West Bandung District Health Office and the Nutrition Section Staff who is a D4 Nutrition graduate has worked for 14 years. Meanwhile, the additional informant worked at the Sindangkerta Health Center who served as the Head of the Health Center and the Nutrition Officer. The head of the Puskesmas is a doctor who has worked for 5 years. The Nutrition Executive is a D3 Nutrition graduate and has just started working in 2020.

\section{Stunting Situation}

West Bandung Districtis one of the priority Regencys/cities for stunting intervention that has been set since 2018. Figure 1 shows the prevalence of stunting in West Bandung District based on a national survey: 


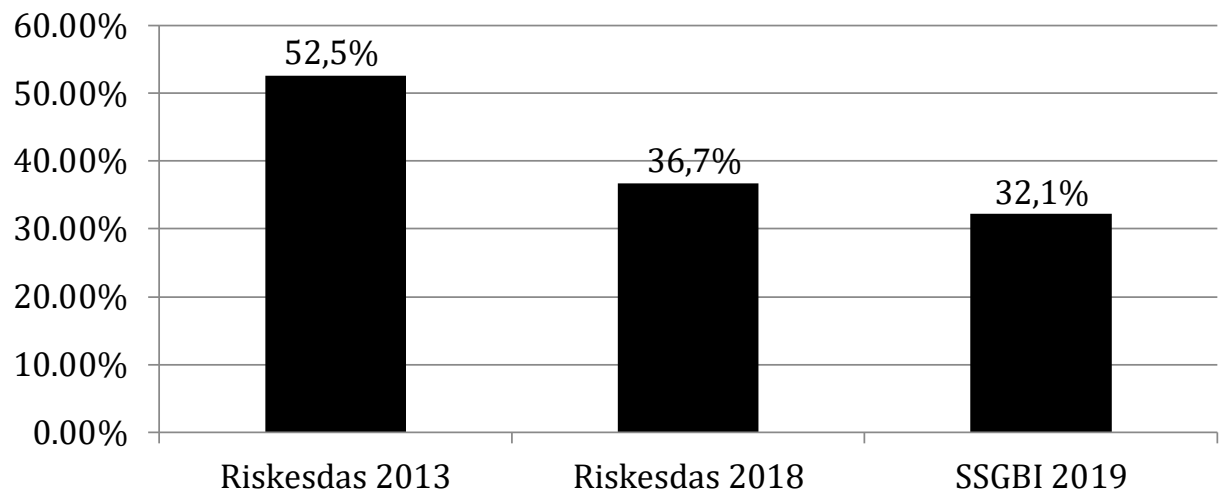

Sources : (2-4)

Figure 1. Stunting Prevalence in West Bandung District

From the picture above, it is known that the prevalence of stunting in West Bandung District according to a national survey from 2013 - 2019 continues to decline. However, there is a fairly large gap between national data and absolute data from the West Bandung District Health Office. Figure 2 shows the prevalence of stunting in West Bandung District based on data from the West Bandung District Health Office:

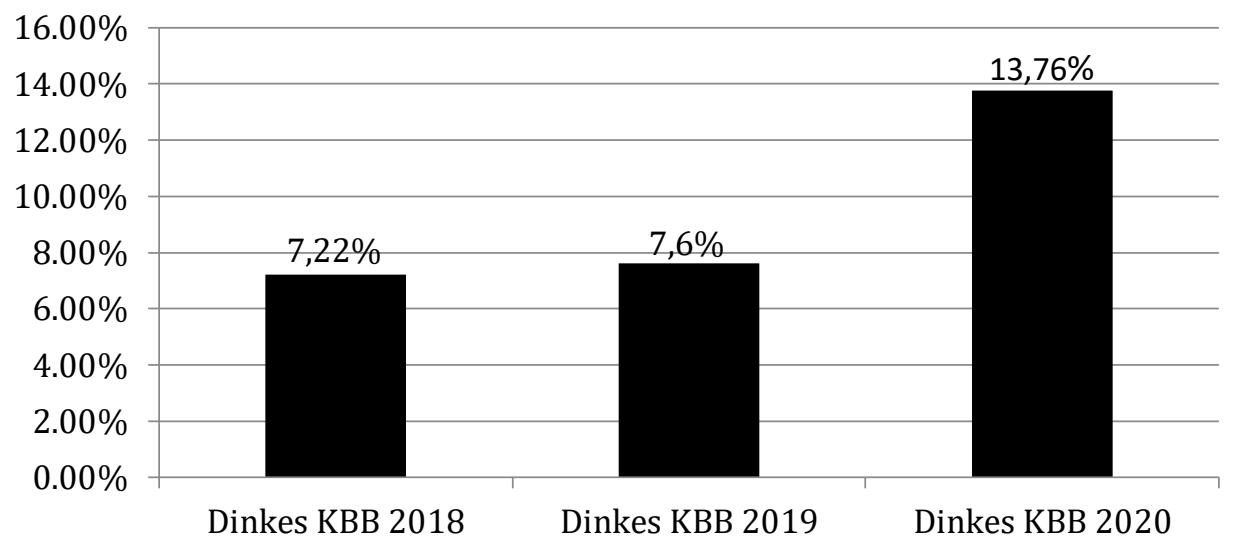

Sources : $19-21$

Figure 2. Stunting Prevalence in West Bandung District

"The results of the national survey may be due to sampling. But shouldn't the sampling method result be more representative? At that time, there were also village heads who did not accept why my village was the locus of stunting, we also know that the prevalence of stunting is still a divine mystery why it could be so far away. But 7\% of our data has the name and address of the toddlers. Then seen from the participation of toddlers who weighed 7\%, we are above $80 \%$, so we dare to say the number because if it is above 80 , it can be used as a portrait, representing it" (Staff of the Nutrition Section of the West Bandung Health Office, 2021).

This data gap needs further investigation. However, in this study, researchers prefer to focus on changes in stunting prevalence before and during the COVID19 pandemic. From Figure 2 above, it is known that there was $6.16 \%$ increase in the prevalence of stunting between before and during the COVID-19 pandemic 
(2019-2020) from $7.6 \%$ to $13.76 \%$. Despite an increase in stunting prevalence from 2018-2020, the Health Department stated that based on data from the Health Department, West Bandung District has succeeded in achieving the national target of reducing stunting prevalence, which is 14\% in 2024.

According to research informants, the factors that are suspected of causing an increase in the prevalence of stunting during the COVID-19 pandemic in West Bandung District include the changes system to a new data input application, the disturbance of health services such as growth and development monitoring of toddlers and nutritional counseling, and not all communities including nutrition officers and cadres can adapt to the pandemic situation and digitize nutrition programs especially in rural areas, and the application of COVID-19 protocols. However, the hope of the West Bandung District Health Office regarding the increase in stunting prevalence in 2020 which coincides with the COVID-19 pandemic is the result of the changes of the data input system which has just been changed from a manual to a digital system in the form of the e-PPGBM (Community-Based Nutrition Recording and Reporting) application which allows for data input errors such as inverted in entering weight and height data. In addition, not all data can be validated one by one by the Health Department because of the large number of children under five who are entered in the application. In addition, efforts to prevent and control stunting in West Bandung District during the COVID-19 pandemic also encountered obstacles related to COVID-19 protocols.

".....now there is an e-PPGBM application, so in 2020 they only input data from the weighing and measurement results according to the data that the application asks for, so they don't need to manually collect data from excel. It's just that maybe the lack of data has gone up so much, I don't know but where did it come from, I hope it's possible from data that has not been validated or entered data incorrectly, because there is some data that we have checked, which should probably be height but is filled in the weight column. If it's like that, many children will be stunted" (Nutrition Section Staff of West Bandung District Health Office, 2021).

According to the results of the researcher literature study, based on the 2018 West Bandung health profile and the 2019 West Java health profile, the people of West Bandung Districtactually have sufficient access to be able to implement clean and healthy living behaviors and community-based total sanitation as an effort to prevent stunting. However, more efforts or special strategies are needed in changing people's behavior and the need for expansion of case finding and services for infectious diseases such as diarrhea and pneumonia in children under five in West Bandung District.

\section{COVID-19 Situation}

COVID-19 cases in West Bandung Districtfrom March 2020 to March 2021 continue to grow and vary in each region. However, with the increase in the number of COVID-19 cases, people's fears are decreasing because they are familiar with it. For the spread of COVID-19 cases, there is a zoning area in West Bandung District which generally includes a green zone and a yellow zone. Various efforts have been carried out by the West Bandung District Health Office and its network in order to prevent and cope with COVID-19 including providing education (either directly such as mobile wars or through print media, social media, and radio), 
distributing masks, installing educational media such as posters in strategic places, implementing the 3T system (Tracing, Testing, Treatment), monitoring the evaluation of COVID-19 protocols in recreational areas and public places, swabs and rapid tests and administering vaccines.

\section{E. Implications of the COVID-19 Pandemic on Stunting}

1. Differences in Stunting Intervention Policies/Programs Before and During the COVID-19 Pandemic

The point of difference in the implementation of stunting intervention policies/programs between before and during the COVID-19 pandemic in West Bandung District is that the implementation of policies/programs must be carried out by prioritizing COVID-19 protocols and making more use of online media to coordinate with networks and across sectors as well as to carry out activities to the public. This is in accordance with Presidential Decree (Keptusan Presiden No. 11 of 2020) and Government Regulation (Peraturan Pemerintah No. 21 of 2020) concerning large-scale social restrictions and derivative policies from local governments. In addition, the Ministry of Health through the Director General of Public Health, dr. Kirana Pritasari, MQIH also stated that nutritional interventions during the COVID-19 pandemic must continue to be carried out by practicing COVID-19 protocols (Firmansyah, 2020).

"First, the difference is from the method, maybe after the pandemic we limit the number of participants maybe no more than $25 \%$ of the room capacity if it's a form of meeting, even if we have to face to face for counseling we can use safe personal protective equipment. Proceed now if what you prioritize first the COVID-19 protocosl" (Nutrition Section Staff of West Bandung District Health Office, 2021).

"...if necessary we can also hold a zoom meeting, but so far our communication is mostly in WA groups, we also have a special WA group for focus location of stunting, so during the pandemic we use that communication more" (Nutrition Section Staff of West Bandung District Health Office, 2021).

"We will direct the Integrated Healthcare Center especially those in the red zone to telecounseling..." (Nutrition Section Staff of West Bandung District Health Office, 2021).

"Currently, online activities do not exist because the situation is not possible, it's not like in urban areas. Here, it depends on signal and facilities. So we don't have an online program yet" (Head of Sindangkerta Health Center, 2021).

2. Impact of the COVID-19 Pandemic on Stunting Prevention and Control Policies/Programs

a. Reallocation and delay in disbursement of stunting budget

There is a re-planning due to the stunting budget being reallocated for COVID-19. The reallocated stunting budget is sourced from the Regency goverment budget (Anggaran Pendapatan dan Belanja Daerah/APBD). Meanwhile, the stunting budget sourced from the central 
goverment (Anggaran Pendapatan dan Belanja Negera-Dana Alokasi Khusus Non Fisik/APBN-DAK Non Fisik) did not experience reallocation but experienced delays in disbursement in addition to its limited allocation because it had been determined by the central government. Meanwhile, stunting funding for Public health center, namely health operational assistance (Batuan Operasional Kesehatan/BOK) which is also sourced from the APBN-DAK Non Fisik, has been reduced for the purchase of personal protective equipment and all necessities for COVID-19.

"From the APBD there is refocusing for COVID, but DAK Non Fisik from the central government, there is no refocusing, but it is limited" (Head of Public Health of West Bandung District Health Office, 2021).

"...The APBN is safe, meaning that stunting fund is not disturbed at all by the presence of COVID, but we don't know why it came down at the end, so they can't be absorbed either" (Nutrition Section Staff of West Bandung District Health Office, 2021).

"For now, there is BOK funding. For stunting funds, it is not determined that this must be so, so it is used as needed. For BOK, I think that's enough for now, maybe we can focus on personal protective equipment for COVID-19 and so on, therefore we reduce funding for stunting " (Head of Sindangkerta Health Center).

Reallocating or refocusing the stunting budget for COVID-19 is not in line with the instructions and efforts made by the central government. President Joko Widodo has indeed ordered Ministries/Institutions and Regional Governments to change the focus of using the APBN and APBD through Presidential Instruction (Inpres Number 4 of 2020) concerning Refocussing Activities, Budget Reallocation and Procurement of Goods and Services in the Context Acceleration of Handling Corona Virus Disease 2019 (COVID-19). The budget that was ordered to be reallocated by way of revision and resubmission to the Ministry of Finance is a non-priority budget (22). Meanwhile, stunting is one of the national priorities. In addition, the APBN to tackle stunting was increased from IDR 39.8 trillion in the 2020 APBN (23).

b. Obstacles in monitoring the growth of children under five at the Integrated Healthcare Center

There is a cumulative decline in the SKDN indicator based on the SKDN in 2019 (before the COVID-19 pandemic) and 2020 (during the COVID-19 pandemic) in the work area of the West Bandung District Health Office. SKDN is a recording and reporting system the results of weighing toddlers at the Integrated Healthcare Center within the scope Ward. From the K/S indicator (program coverage) there was a decrease of $31.78 \%$, the $\mathrm{N} / \mathrm{S}$ indicator (program achievement) decreased by $31.83 \%$, the $\mathrm{D} / \mathrm{S}$ indicator (community participation or the number of children under five who were weighed) decreased by $39.51 \%$, and the $\mathrm{D} / \mathrm{K}$ indicator (program continuity) decreased by $21.43 \%$. Meanwhile, the N/D indicator that describes the success of the program or the tendency of the nutritional status of children under five who are weighed slightly increased by $0.98 \%$. 


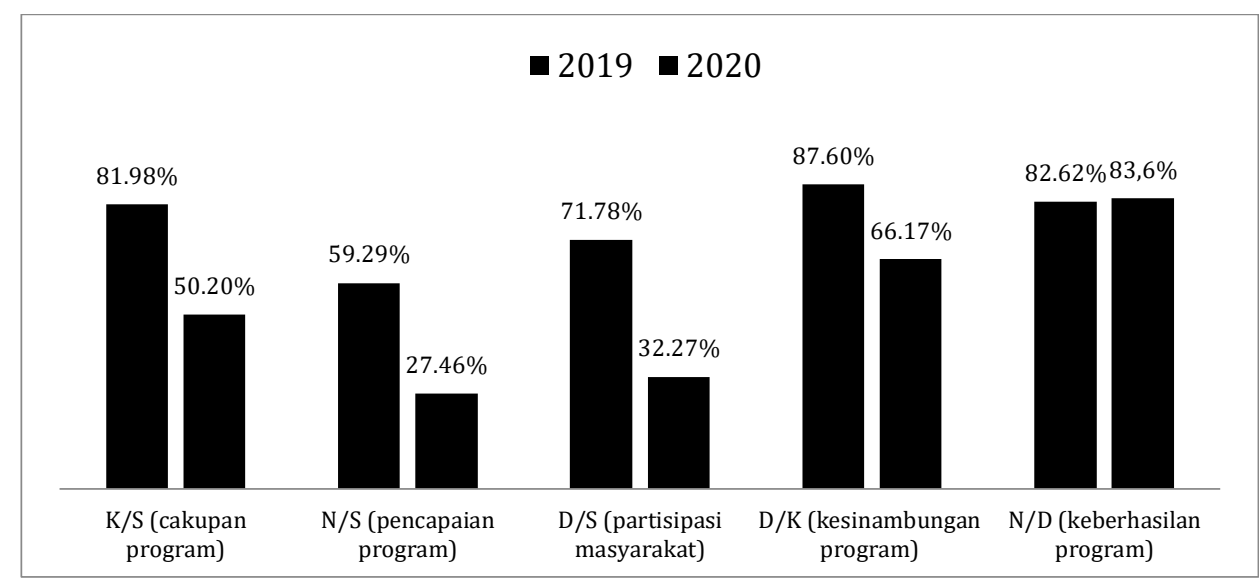

Sources : (24-25)

Figure 3. SKDN indicators for West Bandung District

The delay in monitoring the growth of children under five in the work area of the West Bandung District Health Office which causes a decrease in the achievement of the SKDN indicator does not occur in all regions and does not occur every month. This varies between regions in each month. In 2019 until February 2020 (before the COVID-19 pandemic), there were no blank weighing reports. Meanwhile, starting in March 2020 (when there were COVID-19 cases) there were sub-Regencys with empty weighing data.

"Integrated Healthcare Center had stopped, but not until 23002300 stopped" (Nutrition Section Staff of the West Bandung District Health Office, 2021).

According to the Guidelines for Toddler Health Services during the COVID19 Emergency Response Period issued by the Indonesian Ministry of Health (2020), services for toddlers during the COVID-19 pandemic in an area are determined by local government policies (up to village head policies) and case developments. COVID-19 in the region. If the large-scale social restrictions policy applies or there are positive cases of COVID-19, the Integrated Healthcare Center that provides services for toddlers will be postponed first. The monitoring activities for toddlers' growth and development are carried out at home independently with the help of the Maternal and Child Health Handbook (Buku KIA). If there are toddlers at risk, immunization services, vitamin A, are carried out through appointments/teleconsultation/home visits.

However, when the service for toddlers at the Integrated Healthcare Center is closed, not all of the people of West Bandung District can carry out monitoring of toddler growth and development independently or make appointments/teleconsultation/home visits as directed by the Ministry of Health. In addition, during the COVID-19 pandemic, people also automatically limit their access to health facilities because they are afraid.

We also can't provide transportation for cadres who make home visits, if we want to be monitored at home, not everyone has a steelyard or scales, they don't have the facilities" (Head of Public Health, West Bandung District Health Office, 2021). 
"It's not because it's banned, it's just that the people are already afraid" (Sindangkerta Health Center Nutrition Officer, 2021).

c. Limited health services and the suspension of several Public health center activities related to stunting

There has been a decrease in Public health center visits due to the stipulation of a policy on limiting health services at the Puskesmas in a preventive effort to prevent COVID-19, one of which is through a circular letter from the Head of the West Bandung District Health Office Number 440/1622/DINKES issued on Thursday, March 26, 2020. With the issuance of a letter, this makes the Public health center only provide emergency services.

The Sindangkerta Health Center's innovation programs to accelerate stunting reduction, namely the Ikan Bakar and Goreng Mas Kepiting, which were initially routinely carried out at least once a month were forced to stop. The Sindangkerta Health Center admitted that it was difficult to focus on stunting handling programs in the midst of the COVID-19 pandemic.

"Especially on this year, we don't focus on programs anymore, it means that the focus on program is a few percent, the focus of health problems right now is COVID" (Head of the Sindangkerta Health Center, 2021).

In addition, based on the checklist matrix filled in by Sindangkerta Health Center Nutrition Officer, she stated that stunting consultation activities, development of Human Development Cadres (KPM), micronutrient supplementation (such as calcium supplementation for pregnant women and zinc supplementation for children with diarrhea), pregnancy checkups, immunizations, growth monitoring, and the integrated management of sick toddlers also briefly stopped in 2020 .

However, when compared to the Technical Guidelines for Community Health Center Services during the COVID-19 Pandemic Period from the Ministry of Health (2020), the public health efforts or work program of the Sindangkerta Health Center that should have been allowed to stop during the COVID-19 pandemic were only KPM training. Other public health efforts must still be implemented with adjustments.

\section{The COVID-19 Pandemic Barriers to Stunting Prevention and Control} Policies/Programs in West Bandung District

a. Lack of community participation and difficulty in changing people's behavior

Lack of community participation is associated with people who expect money assistance when participating in every activity, are worried about opening a Integrated Healthcare Center, and do not understand the urgency of weighing and implementing Integrated Healthcare Center activities and there are people who complain about economic problems. Meanwhile, the Health Department cannot impose a will or impose certain sanctions. 
"....the obstacle is the participation of the community when there are stunting in the area, if we give directions, it's identical to money assistance, so maybe our obstacle is in community participation" (Head of Public Health, West Bandung District Health Office, 2021).

"Actually, for the green zone, it's safe if there is a Integrated Healthcare Center, but there are people who have a mindset that it's okay if they don't open a Integrated Healthcare Center" (Nutrition Section Staff of the West Bandung District Health Office, 2021).

"Then the third is the economic obstacle from the community, there are people who complain because of their difficult economic conditions" (Head of Sindangkerta Health Center, 2021).

b. Limited movement due to budget limitations, large-scale social restrictions policies and the need to implement COVID-19 health protocols

The limitation of the budget means that the budget sourced from the central goverment (APBN) cannot be used according to needs/intentions, but the allocation has been determined. The Minister of Health of the Republic Indonesia's Regulation Number 12 of 2021 concerning Technical Guidelines for the Use of Special Non-Physical Allocation (DAK) Funds for the Health Sector for the 2021 Fiscal Year, it has been regulated that stunting funding for the Health Department and Public health center obtained from the Non-Physical Special Allocation Fund (DAK) for the Health Sector, especially the type of health operational assistance (BOK) stunting whose allocation has been determined, namely to support stunting reduction programs in accordance with 8 integrated actions which include the preparation of local regulations related to stunting, mapping and analysis of the stunting program situation, implementation of stunting consultations, human development cadre development, stunting measurement and publication, recording and reporting, and for the annual performance review of stunting integration actions.

"Our limitation is the budget, for example we get a budget for stunting, the budget has been determined by the central government, it means that when we want to go to a program, we can't, because the central government has directed the allocation for $A, B, C$, etc." (Head of Public Health of West Bandung District Health Office, 2021).

In addition, this budget is also limited in quantity due to the refocusing for COVID-19 which sourced from the APBD. The inflexibility to carry out stunting interventions during the COVID-19 pandemic is also due to the implementation of the large-scale social restrictions policy and the need to implement health COVID-19 protocols when carrying out activities.

"....we have limitations on movement. Then funds from other sections/division are limited because we only rely on funds from the $A P B D$. But for the nutrition section, it's because there are funds from the APBN so we can continue to carry out activities" (Nutrition Section Staff of the West Bandung District Health Office, 2021). 
"The effectiveness of stunting intervention in the COVID era is still constrained because if we want to go to the field, we also need swabs and all kinds of things for qualify COVID-19 health protocols" (Head of Public Health of West Bandung District Health Office, 2021).

\section{F. Policy Implementation Strategy of West Bandung District Health Office in Stunting Intervention during the COVID-19 Pandemic}

a. Role division approach

The division of roles carried out by the West Bandung District Health Office in stunting interventions includes sensitive interventions and specific interventions. This division of roles is carried out internally and with external parties of the Health Department in accordance with the main tasks and authorities of each field/institution.

"Through the role division approach, who is sensitive and who is specific, that's our strategy" (Head of Public Health of West Bandung District Health Office, 2021).

"We are under the coordinator of Bappeda, we can integrate with other SKPD (Regional Work Units) or work according to our respective duties" (Staff of the Nutrition Section of the West Bandung District Health Office, 2021).

The Health Department, which is one of the SKPD/OPD (Regional Work Units), is involved in the integration action coordinated by Bappeda and can collaborate with other SKPD/OPD directly or run according to our respectiveduties. The role division strategy where the Health Department focuses more on specific nutrition interventions is in accordance with the directives of the central government, one of which is contained in the Guidelines for Implementing Integrated Stunting Reduction Interventions in Regencys/Cities.

b. Take advantage of digital media

The use of digital media is carried out to coordinate with fellow policy makers, either institution at the top level, at the same level, nor the network under the Health Department. The communication media that are often used are WhatsApp groups and Zoom cloud meetings. In addition, the West Bandung District Health Office also directs digital media as a medium of service, education, and information to the public.

"The effectiveness of stunting intervention in the COVID era is still constrained because if we want to go to the field, we also need swabs and all kinds of things for qualify COVID-19 health protocols, but we don't despair because there are electronic media that we can use for communication to the Public health center and Puskesmas directly to the community " (Head of Public Health of West Bandung District Health Office, 2021).

During the COVID-19 pandemic, the West Bandung District Health Departement made more use of online platforms to educate and direct its network to make more use of digital media in accordance with the instructions of the Ministry of Health. The use of digital media to carry out 
socialization and communication to the community is further returned to the network Public health center.

c. Every activity is carried out in accordance with COVID-19 health protocols Since the COVID-19 pandemic, the implementation of the COVID-19 health protocol is a very important consideration in carrying out activities, especially activities carried out offline. The implementation of stunting intervention activities during the COVID-19 pandemic with a strategy of prioritizing the COVID-19 health protocol in accordance with the direction of the Ministry of Health and various guidelines from the central and local government.

"So maybe the face-to-face method and gathering people are changed..... even if we have to face to face we will definitely think about complying with the strict COVID-19 health protocol so that it means preventing the spread of COVID" (Nutrition Section Staff of the West Bandung District Health Office, 2021).

d. Holding Integrated Healthcare Center "Sweeping" Integrated Healthcare Center "sweeping" is a home visit by cadres to measure the weight and height of toddlers and provide vitamin A supplementation. Integrated Healthcare Center sweeping activities is a recommendation from the Ministry of Health so that data on growth and development of toddlers can be documented during the COVID-19 pandemic while still implementing the COVID-19 health protocols. However, the Integrated Healthcare Center "sweeping" was not carried out uniformly in West Bandung District. The West Bandung District Health Office also admitted that it could not force cadres because there were no additional incentives.

"There are also those who go around to people's homes, don't open Posyandu, bring scales and height measuring devices, measured in front of the house while giving vitamin A" (Staff of the Nutrition Section of the West Bandung District Health Office, 2021).

"We have made a circular policy from the head of the service to open Posyandu, but if the people don't want it, what can we do, at least with this strategy, cadres pick up the ball. We also can't provide transportation for the ball pick-up cadres, so basically, if we want to be monitored at home, not everyone has a steelyard or scales, they don't have the facilities" (Head of Public Health, West Bandung District Health Office, 2021).

e. Using priority strategies to streamline the budget

Using priority strategies to streamline the budget is done by choosing between prevention or intervention measures according to the causes of stunting. For example, cases of stunting in toddlers from underprivileged families were found, then the intervention was carried out by providing supplementary feeding. While for stunting toddlers from prosperous families, the stunting interventions selected include counseling on infant and child feeding and giving stimulants.

"In my opinion, this budget is insufficient, but we are using a priority strategy, which one is more priority, whether in intervention, or for prevention. So be smart in making strategies with all limitations" (Head of Public Health at the West Bandung District Health Office, 2021). 
"If there is a stunting case, we will look at the background first, if the family can't afford it, we will give supplementary feeding if the family is prosperous, we will look at their behavior with PMBA counseling, we also give stimulants for babies under the red line" (Head of Public Health at the West Bandung District Health Office, 2021).

f. Synergize the COVID-19 prevention program with stunting The West Bandung District Health Office stated that they would allocate a budget of $8 \%$ for the stunting prevention program in synergy with the COVID19 prevention program in 2021 in accordance with the direction of the central government. This policy also applies to the Public health center budget.

"For the program, there is a discourse that we are asked to prepare for 2021 while the budget has not been determined, there is a possibility that 8\% of our program budget is asked for activities whose direction must be for the prevention and control of COVID-19. So synergized. Everything is focused on that, including the puskesmas" (Staff of the Nutrition Section of the West Bandung District Health Office, 2021).

Synergizing the COVID-19 prevention program with stunting prevention is also a directive from President Joko Widodo to the ranks of ministries and institutions including the Ministry of Health and the Ministry of Social Affairs (as in the distribution of social assistance). This synergy effort is aimed at the sustainability of the stunting prevention program during the COVID-19 pandemic (26).

G. Analysis of the Effectiveness of Policy Implementation Strategy of the West Bandung District Health Office in Stunting Interventions during the COVID19 Pandemic

According to the theory of Edward III (1980), there are four main issues that affect the effectiveness of a policy implementation, namely aspects of communication, resources, disposition, and bureaucratic structure (27).

1. Communication

The West Bandung District Health Office has good communication with its network (Public health center), the central government, provincial governments, district governments, and other regional apparatus organizations both within one clump and across sectors. The West Bandung District Health Office stated that they had received directions from the district, provincial and central government regarding stunting and always reshared the information obtained to the Puskesmas as its network to continue to work on stunting. In addition, the West Bandung District Health Office also has a collaboration program with Non-Government Organizations (NGOs).

However, the hope from the Sindangkerta Health Center is that the West Bandung District Health Office will be more monitor and communicative with the problem of stunting toddlers during the COVID-19 pandemic.

"I hope that stunting will be monitored more closely, because there is not enough information about stunting from the Department, but it's difficult when it comes to COVID" (Sindangkerta Health Center Nutrition Officer, 2021). 
Meanwhile, direct communication to the community according to Wulandari (2019) who conducted research related to the implementation of stunting policies in West Bandung District, she found that socialization to the community was considered uneven because there were still some people who did not understand how to prevent stunting (28).

2. Resources

Health resources, especially Integrated Healthcare Center cadres in West Bandung District and health workers at the Integrated Healthcare Center (especially at the Sindangkerta Public Health Center which is the research site) were considered sufficient to be able to carry out stunting interventions. However, in terms of quality, health resources in Bandung Regency generally do not have a good communication strategy for optimal stunting interventions.

"Inshallah there will be enough human development cadres, maybe it's just a matter of empowering them later" (Nutrition Section Staff of the West Bandung District Health Office, 2021).

"....health workers must know about stunting, but there is no communication strategy to prevent stunting. 80\% of health workers should be trained on communication strategies for behavior change to prevent stunting, but we haven't been able to train that many health workers" (Head of Public Health at the West Bandung District Health Office, 2021).

Resources in terms of infrastructure/health care facilities that can support stunting interventions in West Bandung District are considered sufficient because there are 32 Public health center for 16 sub-districts in West Bandung District. However, in stunting interventions during the COVID-19 pandemic, health care facilities need to be equipped with COVID-19 health protocols to prevent transmission of the virus which was previously not budgeted for and not all people have adequate tools/facilities in order to independently monitor the development of toddlers at home.

"There are 32 health centers, that's what we can use" (Head of Public Health at the West Bandung District Health Office, 2021).

"Maybe that's all, if the Integrated Healthcare Center wants to be held, it may be equipped with Personal Protective Equipment (PPE). This means that so that cadres do not become a source of spread, they must wear PPE such as masks, face shields, hand sanitizer, hand washing facilities, etc. There is at least one hand washing place at the Integrated Healthcare Center. Then if you count at the cadre's table at least 5, it means 5 times the amount of the budget that was not previously budgeted" (Nutrition Section Staff of the West Bandung District Health Office, 2021).

"... if we want to be monitored at home, not everyone has a steelyard or scales, they don't have the facilities" (Head of Public Health, West Bandung District Health Office, 2021).

In terms of financial resources, the Health Operational Assistance (BOK) fund which is a source of funding for services at the Public health center is 
considered sufficient (according to the statement of the Sindangkerta Health Center) in the current stunting prevention and control effort. Meanwhile, the West Bandung District Health Office gave different information. The staff of the Nutrition Section provided information that the budget for the Nutrition Section itself was considered sufficient because there was a special allocation from the APBN. However, according to the view of the Head of Public Health who is in charge of 3 Sections (Nutrition Section, Family Health Section, Environmental Health Section and Occupational Health), the current budget is considered insufficient so it is necessary to carry out a special strategy.

"For the BOK, I think that's enough for now" (Head of Sindangkerta Health Center, 2021).

"In terms of nutrition, the current budget is sufficient..." (Nutrition Section Staff of the West Bandung District Health Office, 2021).

"In my opinion, this budget is insufficient, but we are using a priority strategy..." (Head of Public Health, West Bandung District Health Office, 2021).

3. Disposition

The West Bandung District Health Office understands its role and can act in accordance with its domain, can be cooperative and willing to commit to central and local government policies as well as cross-sector efforts that are in line with stunting prevention and control, are able to set priorities including when in an emergency/limited condition and try to to adapt to changes and limitations even though society has not been fully able to follow. However, it requires alignment of commitment and cooperation from the network under the Health Office and the people of West Bandung District.

"The commitment is inter-sectional, inter-programme, cross-sectoral integration, where we also have a policy in the form of a decree for the acceleration of stunting reduction team led by BAPPEDA" (Head of Public Health, West Bandung District Health Office, 2021).

"In terms of stunting, we think we might be given a secondary position because right now if we provide counseling, it is related to preventing crowds. It is impossible to collide with what we require the community to comply with COVID-19 health protocols" (Head of Sindangkerta Health Center, 2021).

\section{Bureaucratic Structure}

The West Bandung District Health Office is incorporated into the system in an integrated action with other Regency/City Regional Apparatus Organizations under the coordination of BAPPEDA (Development Planning Agency at SubNatiional Level) and refers to the guidelines from BAPPENAS (Minister of National Development Planning) namely "Guidelines for Implementing Integrated Stunting Reduction Interventions in Regency/City" which can be used to plan, implement, monitor, evaluate, and report in the context of implementing integrated stunting reduction interventions. In addition, there are guidelines for health services during the COVID-19 pandemic. However, 
these guidelines are still separate and there are no specific stunting intervention guidelines during the COVID-19 pandemic.

\section{CONCLUSION}

Based on the results of qualitative research that has been carried out by researchers, it can be concluded that:

a. There was an increase in the prevalence of stunting in West Bandung District by $6.16 \%$ from $7.6 \%$ in 2019 (before the COVID-19 pandemic) to $13.76 \%$ in 2020 (during the COVID-19 pandemic). Meanwhile, according to the zoning distribution of COVID-19, West Bandung District was mostly in the yellow and green zones (at the time of the study).

b. The implications of implementing COVID-19 prevention and handling policies on stunting interventions, especially specific nutrition interventions in West Bandung District, include the implementation of policies/programs that must be implemented by prioritizing health protocols, making more use of online media, reallocations and delays in the disbursement of stunting budgets, obstacles in monitoring the growth of children under five at the Integrated Healthcare Center, limited health services and the suspension of several Public health center activities related to stunting.

c. The strategy for implementing the policies of the West Bandung District Health Office in stunting interventions, especially specific nutrition interventions during the COVID-19 pandemic, including through a role-sharing approach, take advantage of digital media, every activity carried out in accordance with COVID-19 health protocols, Holding Integrated Healthcare Center "Sweeping", using priority strategies to streamline the budget, and synergize the COVID-19 prevention program with stunting.

d. Based on the researcher's analysis of the effectiveness of implementing the policies of the West Bandung District Health Office in stunting interventions during the COVID-19 pandemic, the results show the following:

1) In terms of communication and bureaucratic structure, it is considered to have been well supported to implement stunting intervention policies during the COVID-19 pandemic.

2) In terms of infrastructure/health service facilities, it is considered sufficient. However, stunting interventions during the COVID-19 pandemic need to be equipped with COVID-19 health protocols and not all communities have adequate tools/facilities in order to independently monitor toddler growth and development.

3) In terms of human and financial resources, it is considered not evenly distributed in every sector/agencies to implement stunting intervention policies during the COVID-19 pandemic.

4) In terms of disposition, it is considered to have supported well to implement stunting intervention policies during the COVID-19 pandemic, but it requires alignment of commitment and cooperation from the network under the Health Service and the people of West Bandung District.

\section{ACKNOWLEDGEMENT}

All authors declared no potential conflicts of interest with respect to the research, authorship and/or publication of this article. 


\section{ACKNOWLEDGEMENT}

We would like to thank all the participants in West Bandung District Health Office and Sindangkerta Health Center who took part in this research.

\section{REFERENCES}

1. Kemenkes RI (2007). Riset Kesehatan Dasar (Riskesdas) 2013. Lembaga Penerbitan dan Pengembangan Kementerian Kesehatan Republik Indonesia (Kemenkes RI), Jakarta.

2. Kemenkes RI (2013). Riset Kesehatan Dasar (Riskesdas) 2013. Lembaga Penerbitan dan Pengembangan Kementerian Kesehatan Republik Indonesia (Kemenkes RI), Jakarta.

3. Kemenkes RI (2018). Riset Kesehatan Dasar (Riskesdas) 2018. Lembaga Penerbitan dan Pengembangan Kesehatan Kementerian Kesehatan Republik Indonesia (Kemenkes RI), Jakarta.

4. Badan Pusat Statistik (2019). Profil Statistik Kesehatan, Badan Pusat Statistik, Jakarta.

5. Pusat Data dan Informasi Kementerian Kesehatan (2018). Buletin Jendela Data dan Informasi Kesehatan: Situasi Balita Pendek (Stunting) Di Indonesia. Kementerian Kesehatan Republik Indonesia, Jakarta.

6. World Health Organization Expert Committee (1995) Report of WHO Expert Committee, Technical Report Series No. 845: Physical Status The Use and Interpretation of Anthropometry. From http://whqlibdoc.who.int/trs/WHO_TRS_854.pdf.

7. Kementerian PPN/Bappenas (2018). Pedoman Pelaksanaan Intervensi Penurunan Stunting Terintegrasi di Kabupaten/Kota. Kementerian PPN/Bappenas, Jakarta.

8. Pritasari, K (2020) Arah Kebijakan dan Rencana Aksi Program Kesehatan Masyarakat Tahun 2020 - 2024. Direktorat Jenderal Kesehatan Masyarakat Kementerian Kesehatan Republik Indonesia, Jakarta.

9. Winahyu, AI (2020). Pandemi COVID-19 Berpotensi Ancam Target Penurunan Stunting. Media Indonesia.

From https://m.mediaindonesia.com/infografis/detail_infografis/342872-pandemi-covid19-berpotensi-ancam-target-penurunan-stunting?utm_source=dable

10. Komisi IX Dewan Perwakilan Rakyat Republik Indonesia (2020). Jangan Kesampingkan Program Pencegahan Stunting Di Masa Pandemi, Pemerintah Republik Indonesia. From www.dpr.go.id/berita/detail/id/29080/t/

11. United Nation International Children Emergency Fund 2020, COVID-19 and Children in Indonesia. UNICEF. From https://www.unicef.org/press-releases/un-launchesglobal-

12. Dinas Kesehatan Provinsi Jawa Barat (2017). Profil Kesehatan Dinas Kesehatan Provinsi Jawa Barat 2017. Dinas Kesehatan Provinsi Jawa Barat, Bandung.

13. Izwardy, Doddy. 2020. Studi Status Gizi Balita Terintegrasi SUSENAS 2019.Rakerkesnas Jakarta 20 Februari 2020.

14. Susanti, R (2019). Atalia Ridwan Kamil Akui Angka Stunting di Jawa Barat Cukup Tinggi. 
https://regional.kompas.com/read/2019/10/17/07292841/atalia-ridwan-kamilakui-angka-stunting-di-jawa-barat-cukup-tinggi

15. Badan Pusat Statistik Provinsi Jawa Barat (2017). Provinsi Jawa Barat dalam Angka 2017. Badan Pusat Statistik Provinsi Jawa Barat, Bandung.

16. Mohamad, A (2020). Sepuluh Desa di KBB Masuk Zona Stunting, Ini Langkah Pemkab Bandung Barat. Bosscha.id. Form https://bosscha.id/2020/08/11/sepuluh-desa-dikbb-masuk-zona-stunting-ini-langkah-pemkab-bandung-barat/

17. Syahrani, LD (2019). Faktor Resiko Stunting pada Balita (1-5 tahun) di Kabupaten Bandung Barat. Universitas Pendidikan Indonesia. From http://repository.upi.edu/36962/1/TA_JKR_1602090_Title.pdf

18. Husodo, HS (2018). 10.487 Balita di Bandung Barat Alami Stunting. Pikiran Rakyat. From https://www.pikiran-rakyat.com/bandung-raya/pr-01299229/10487-balita-dibandung-barat-alami-stunting-427303

19. Dinas Kesehatan Kabupaten Bandung Barat (2018). Data Stunting Kabupaten Bandung Barat.

20. Dinas Kesehatan Kabupaten Bandung Barat (2019). Data Stunting Kabupaten Bandung Barat.

21. Dinas Kesehatan Kabupaten Bandung Barat (2020). Data Stunting Kabupaten Bandung Barat.

22. Seksi Informasi Hukum - Ditama Binbangkum. (2020). Realokasi Anggaran untuk Penanganan Corona., Jaringan Dokumentasi dan Informasi Hukum Badan Pemeriksa Keuangan RI. From https://jdih.bpk.go.id/wp-content/uploads/2020/04/RealokasiAnggaran-utk-penanganan-corona.pdf.

23. Wicaksono, A. (2021). Sri Mulyani Siapkan Rp 40,33 T Atasi Masalah Gizi Kronis 2021. $\begin{array}{lllll}\text { CNN Indonesia } & 24 & \text { Mei } & 2021 . & \text { From }\end{array}$ https://www.cnnindonesia.com/ekonomi/20210524133133-532-646217/srimulyani-siapkan-rp4033-t-atasi-masalah-gizi-kronis-2021.

24. Dinas Kesehatan Kabupaten Bandung Barat (2019). SKDN Dinas Kesehatan Kabupaten Bandung Barat Tahun 2019.

25. Dinas Kesehatan Kabupaten Bandung Barat (2020). SKDN Dinas Kesehatan Kabupaten Bandung Barat Tahun 2020.

26. Pribadi, IA. (2020). Presiden Minta Bansos COVID Sinergi dengan Penanggulangan "Stunting"'. Antaranews.com 5 Agustus 2020. From https://www.antaranews.com/berita/1650382/presiden-minta-bansos-covidsinergi-dengan-penanggulangan-stunting.

27. Edward III, GC. (1980). Implementing Public Policy, Congressional Quarterly Press.

28. Wulandari, RS. (2019). Implementasi Kebijakan Pencegahan Stunting di Kabupaten Bandung Barat. SOSPOL : Jurnal Sosial dan Politik, .24 (2) 102-112. 